\title{
Revised Nomenclature of Specific or Subspecific Epithets That Do Not Agree in Gender with Generic Names That End in -bacter
}

\author{
J. P. EUZEBY* \\ Laboratoire de Bactériologie, Ecole Nationale Vétérinaire, F-31076 Toulouse cedex 3, France
}

\begin{abstract}
The names Acetobacter xylinum, Acetobacter xylinum subsp. sucrofermentans, Acetobacter xylinum subsp. xylinum, Caedibacter caryophila, Campylobacter cryaerophila, Fibrobacter succinogenes subsp. elongata, Iodobacter fluviatile, and Rhodobacter blastica are revised in accordance with Rule $12 \mathrm{c}$ or Rule $13 \mathrm{~b}$ of the International Code of Nomenclature of Bacteria: Bacteriological Code, 1990 revision.
\end{abstract}

The spelling of some specific and subspecific epithets that have been validly published is in violation of Judicial Opinion 3 cited in appendix 5 of the International Code of Nomenclature of Bacteria: Bacteriological Code, 1990 revision (5), and in violation of Rule $12 \mathrm{c}$ or Rule $13 \mathrm{~b}$ of the Bacteriological Code, 1990 revision (5). According to Judicial Opinion 3, the names of bacterial genera which end in -bacter should be considered masculine. According to Rule $12 \mathrm{c}$, a specific epithet treated as an adjective must agree in gender with the genus name, and according to Rule $13 \mathrm{~b}$, a subspecific epithet treated as an adjective must agree in gender with the genus name.

Previously, the epithets of Acetobacter aceti subsp. xylinum (10), Clavibacter iranicum (1), Clavibacter michiganense (1), Clavibacter michiganense subsp. insidiosum (1), Clavibacter michiganense subsp. michiganense (1), Clavibacter michiganense subsp. nebraskense (1), Clavibacter michiganense subsp. sepedonicum (1), and Clavibacter michiganense subsp. tessellarius (1) were revised to Acetobacter aceti subsp. xylinus (5), Clavibacter iranicus (11), Clavibacter michiganensis (11), Clavibacter michiganensis subsp. insidiosus (11), Clavibacter michiganensis subsp. michiganensis (11), Clavibacter michiganensis subsp. nebraskensis (11), Clavibacter michiganensis subsp. sepedonicus (11), and Clavibacter michiganensis subsp. tessellarius (11), respectively.

However, other names have not been corrected. The specific or subspecific epithets of Acetobacter xylinum (2), Acetobacter xylinum subsp. sucrofermentans (4), Acetobacter xylinum subsp. xylinum (4), Caedibacter caryophila (9), Campylobacter cryaerophila (8), Fibrobacter succinogenes subsp. elongata (7), Iodobacter fluviatile (6), and Rhodobacter blastica (3) are adjectives; therefore, these names should be revised to Acetobacter xylinus, Acetobacter xylinus subsp. sucrofermentans, Acetobacter xylinus

* Mailing address: Laboratoire de Bactériologie, Ecole Nationale Vétérinaire, 23 chemin des Capelles, F-31076 Toulouse cedex 3, France. subsp. xylinus, Caedibacter caryophilus, Campylobacter cryaerophilus, Fibrobacter succinogenes subsp. elongatus, Iodobacter fluviatilis, and Rhodobacter blasticus, respectively.

\section{REFERENCES}

1. Davis, M. J., A. G. Gillaspsie, Jr., A. K. Vidaver, and R. W. Harris. 1984 Clavibacter: a new genus containing some phytopathogenic coryneform bacteria, including Clavibacter xyli subsp. xyli sp. nov., subsp. nov. and Clavibacter xyli subsp. cynodontis subsp. nov., pathogens that cause ratoon stunting disease of sugarcane and Bermudagrass stunting disease. Int. J. Syst. Bacteriol. 34:107-117.

2. International Journal of Systematic Bacteriology. 1984. Validation of the publication of new names and new combinations previously effectively published outside the IJSB. List no. 14. Int. J. Syst. Bacteriol. 34:270-271.

3. International Journal of Systematic Bacteriology. 1994. Validation of the publication of new names and new combinations previously effectively published outside the IJSB. List no. 51. Int. J. Syst. Bacteriol. 44:852.

4. International Journal of Systematic Bacteriology. 1996. Validation of the publication of new names and new combinations previously effectively published outside the IJSB. List no. 58. Int. J. Syst. Bacteriol. 46:836-837.

5. Lapage, S. P., P. H. A. Sneath, E. F. Lessel, V. B. D. Skerman, H. P. R. Seeliger, W. A. Clark, and P. H. A. Sneath (ed.). 1992. International code of nomenclature of bacteria:bacteriological code, 1990 revision. American Society for Microbiology, Washington, D.C.

6. Logan, N. A. 1989. Numerical taxonomy of violet-pigmented, gram-negative bacteria and description of Iodobacter fluviatile gen. nov., comb. nov. Int. J. Syst. Bacteriol. 39:450-456.

7. Montgomery, L., B. Flesher, and D. Stahl. 1988. Transfer of Bacteroides succinogenes (Hungate) to Fibrobacter gen. nov. as Fibrobacter succinogenes comb. nov. and description of Fibrobacter intestinalis sp. nov. Int. J. Syst. Bacteriol. 38:430-435.

8. Neill, S. D., J. N. Campbell, J. J. O'Brien, S. T. C. Weatherup, and W. A. Ellis. 1985. Taxonomic position of Campylobacter cryaerophila sp. nov. Int. J. Syst. Bacteriol. 35:342-356.

9. Schmidt, H. J., H. D. Görtz, and R. L. Quackenbush. 1987. Caedibacter caryophila sp. nov., a killer symbiont inhabiting the macronucleus of Paramecium caudatum. Int. J. Syst. Bacteriol. 37:459-462.

10. Skerman, V. B. D., V. McGowan, and P. H. A. Sneath (ed.). 1980. Approved lists of bacterial names. Int. J. Syst. Bacteriol. 30:225-420.

11. Zgurskaya, H. I., L. I. Evtushenko, V. N. Akimov, and L. V. Kalakoutskii. 1993. Rathayibacter gen. nov., including the species Rathayibacter rathay comb. nov., Rathayibacter tritici comb. nov., Rathayibacter iranicus comb. nov., and six strains from annual grasses. Int. J. Syst. Bacteriol. 43:143-149. 